\title{
Disability and Sex: Nepali Disabled Women Writers and Their Quest for the Self
}

\author{
Tulasi Acharya \\ South Georgia State College, Douglas, GA, USA
}

\begin{abstract}
The paper studied the experiences of disability and sexuality in the works of two disabled women writers from Nepal: Jhamak Ghimire and Parijaat (Bishnu Kumari Waiwa). Jhamak Ghimire's autobiographical works and Parijat's novels and poems presented their experiences as the disabled gendered subjects in Nepali society. Using the narrative analysis method, I analyzed Ghimire's Jiwan Kadaki Phool and Samaya-Bimba and Parijat's Shirishko Phool and Mahattahin and other poems. I asked: How did these writers define the concept of disability and desire for love and sex? and how did their definitions challenge the pre-existing notions of the disabled subjects' identities and desires, and dispel the myth of disability as asexual? In representations, the disabled people appear as asexual subjects and, therefore, unfit for sex and marriage. The paper argued that Ghimire and Parijat resisted such discourses and unveiled the disabled women's desires and emotions that people in general failed to acknowledge. Both writers defined the disabled bodies as the site of love, sexuality, and several emotions associated with desire. Reading their texts, I demonstrated how they challenged the normative assumptions about their bodies and explored their sexual selves and gendered identity. By writing about their own bodies and desires in their narratives, Ghimire and Parijat searched for the disabled women's sexual identity in Nepal.
\end{abstract}

Keywords: women with disabilities, Nepal, Parijaat, Ghamak Ghimire, disability, asexual, narratives, identity, self

\section{Introduction}

Women with disabilities are deemed as asexual and incapable, and, therefore, they are, directly or indirectly discouraged to fulfill their desire (McRuer \& Mollow, 2012; Kim, 2012). In the context of Nepal, disabled people, mostly women with disabilities are deemed unfit for marriage and motherhood (Dhungana, 2006). This paper discusses disability and sexual ability of women with disabilities in the context of Nepal, reflecting on the narratives of Jhamak Ghimire and Parijat. In this paper, I have used the narrative analysis method, a method used to underscore the voices of the marginalized - the disabled women in this context - to assess the textual (autobiographical and fictional) narratives of Parijaat and Jhamak Ghimire. Analyzing the narratives of women with disabilities, in the paper, I have unraveled how they explore the beauty of their bodies, their love towards them, and their desire for love. They, through their writings, also reflect how they are fit for marriage and motherhood, dispelling the myth of disabled bodies as "asexual", and embarking on their quest for sexual identity and the self.

Tulasi Acharya, PhD in Public Administration and Policy, professor of English, South Georgia State College, Douglas, USA. 


\section{Disability, Sex, Identity, and Quest for Self}

The recognition of sexual lives of women with disabilities by themselves can mark their understanding of the self - the sexual identity to define themselves. The word "sex" in this paper is attached to the meaning of desire and love and marriage and identifying the self. In Nepal, still the discussion of sex is considered taboo for which gender plays a pivotal role in shaping the perception of both men and women. Their roles are already defined and taken for granted (Acharya, 2005). In this context, if a woman has a disability, that may make the scenario worse because she is deemed unable to meet gender expectations. She is considered as sexually incapable and, therefore, unfit for marriage and bearing children — the idea associated with female empowerment in Nepali context. Gerschick (2000) argued that disability intersects with gender and gender with other "social characteristics including sexual orientations, race, and ethnicity to shape the perceptions, experiences, and life chance of men and women" (p. 1263). These perceptions of viewing women further worsen their sexual lives and their quest for the self. People with disabilities seem to be treated as asexual or genderless human beings, and when a person with a disability is a woman, she has a different life experience due to different social and cultural attributes associated with her. Greene (2015) suggested that the deeply rooted patriarchy in Nepali society controls many areas of women's lives, obliging societal anticipations of marriage, prescribing social roles for them, and indoctrinating them in social value systems. If a woman is disabled, her sex life seems to be under duress because people view her as asexual and as incapable to meet the general socio-cultural expectations of Nepali society. This parochial perception intercepts a woman with a disability from marrying a husband, let alone fulfilling her sexual and psychological needs. As a result, her sexual life and the quest for the self becomesvulnerable.

Shuttleworth, Russel, and Weerakoon (2010) stressed the significance of sexual drive as being "integral to well-being and quality of life" (p. 187) and the identity of the self. Surveys have shown general interest in sexual activity, whether disabled or not (Shuttleworth et al., 2010). Many researchers have emphasized the importance of the association of sex and quality of life (Giami, 1987; Nosek, Howland, Young, Georgiou, Rintala, Foley, Bennett, \& Smith, 1994; Sandowski, 1993). McCabe, Cummins, and Deeks (2000) proposed that sex and quality of life are of particular importance for people with disabilities, "...yet the association has received almost no attention in relation to people with physical disability" (p. 115). Most able-bodied people perceive those with disabilities differently, and people who care for disabled people often "hold negative or patronizing attitudes towards sexual expressions" of the disabled as it is considered "inappropriate" (Shuttleworth et al., 2010, p. 188) that may prevent disabled women from defining their own sexual self-sexual life and identity.

Generally, so-called able-bodied people deem disability and sexual ability to be incommensurate (McRuer \& Mollow, 2012), linking disability with asexuality that discourages disabled women's quest for sexual self and sexual identity. Constructions of asexualness and disability have been and continue to be bound closely together (Cuthbert, 2017). O'Toole and Bregante (1992) underscored the idea that able-bodied people tend to ascribe asexuality to marginalized groups, especially disabled persons. Kim (2011) emphasized the inseparable intersection of normality and sexuality. Kim (2011) proposed that disability "is an embodiment neither to be eliminated, nor to be cured, and is a way of living that may or may not change" (p. 479). This suggests that no one can change the nature of one's body, and a disability should be accepted as a different kind of ability. Rogers (2016) observed that disabled people "do not often get what they desire, for example love, marriage, 
and friends" (p. 619). They feel lonely and want relationships just like able-bodied people. However, those with disabilities who show signs of sexual needs/desires are deemed promiscuous (Rogers, 2016). This idea interferes with disabled women's self-identification of themselves.

In the context of Global North, McCabe (1999) suggested that the sexual feelings of people with disabilities have been neglected and they have been rarely granted sexual rights. McCabe's (1999) studies of sexual knowledge, experience, and feelings among people with disabilities show that the difficulty "stemmed from the negative attitudes generally held by parents and caregivers towards the expression of sexuality among people with intellectual disability" (p. 158). McCabe (1999) found that knowledge about sexuality is not provided to people with disabilities, and because "there is limited discussion about sexuality, negative feelings develop in relation to sexuality and there are low levels of expression of sexuality" (p. 168) which eventually hamper the individual self of people with disabilities — their identity, their sexual life.

\section{Narrative Analysis}

Here, narrative analysis is used as a method to examine the sexual and marital lives of women with disabilities and their quest for the self through their fictional and non-fictional works. Narrative analysis is used to assess personal histories, biography, life history, and auto-biography, as well as fiction, non-fiction, novels, poetry, all of which contain the reflection of lived experiences and their quest for the self (Bamberg, 2003; 2011; Bamberg \& Georgakopoulou, 2008). Thus, narrative has emerged as a new, but central, formatting device for the organization of self and identity. It helps define who we are, or who we think we are, through the realization of the stories we tell about ourselves (Randall, 1995). In this sense, the story becomes the data to be analyzed. Narrative inquiry seeks out the problem in the narratives through the stories that are weaved from the author's experiences, problems, and social and cultural issues and contexts (Chase, 2005). Thus, narrative method is useful for the human sciences (Riessman, 2008).

Czarniawska (2004) defined narrative method as a process that delayers grand narratives in social research. Providing an overview of the development of the narrative approach within the social sciences, Czarniawska (2004) emphasized the importance of narratives for qualitative researchers who want to explore new perspectives, characterizing narrative methods as a "naturalistic genre" (p. 9) since they often reflect everyday life, or the "raw world as was lived and experienced by its subject" (p. 9).

The history of narrative research dates back to hermeneutic studies of the Bible and up to the postmodern method that studies the underlying structure, while explaining the role of the narratives (Czarniawska, 2004; Lyotard, 1984). Narratives are everywhere; we live by narratives (Czarniawska, 2004). Czarniawska (2004) provided a clear overview of how stories are made, collected, provoked, interpreted, analyzed, deconstructed, put together, and set against or together with other stories. The narrative method helps researchers uncover the soft side that natural science has forgotten or left undisturbed (Czarniawska, 2004).

A narrative method is very important to understand the life-world situations of a person, his or her identity, and how a person lives through or by narratives. In this paper, disability narratives facilitate an understanding of the complexity of women and disability, disability and sex and the quest of women with disabilities for the self.

Narrative accounts of the disabled's life events feature emotions and authenticity that cannot be understood until they are shared. The richness of these emotions and the depth of authenticity are achieved through the acknowledgement of the narratives of the disabled by reaching out to the essence of their truthful 
lives. The narratives can aid in understanding the experience of disablement (Malhotra \& Rowe, 2013). Narratives serve a purpose that a quantitative analysis fails to fulfill, especially in understanding the experience of the disabled and its stereotypes (Carbado \& Gulati, 2003). "It brings a human face to the problem, thereby facilitating appreciation of legal barriers and discrimination experienced by marginalized groups including disabled" (Malhotra \& Rowe, 2013, p. 10).

Narratives stress the specificity of experience of a story to convey its verisimilitude (Bruner, 1991). In a narrative research study on disability, Malhotra and Rowe (2013) argued for the phenomenological understanding of women with disabilities which is "difficult for an able-bodied woman to appreciate what it is truly like to require assistance with toileting and bathing on a daily basis as it is for a man to appreciate the experience of child birth" (p. 11).

This underscores the importance of narrative accounts of the disabled to understand the phenomenon of the lived experiences of the disabled, their identity, and the quest for the self. The richness of experience is collected from narratives of the marginalized and disabled (Mahoney, 1991). In this paper, I have used Riesman's (2008) three, except for dialogic, out of four types of analysis to analyze the narratives of Ghimire and Parijat (because I did not have any picture or visual to analyze) to explore their gendered identity and quest for the self.

Table 1

Types of Narrative Analysis

\begin{tabular}{lll}
\hline Types of analysis & Meaning & Application in disability and sexual identity analysis \\
\hline Thematic analysis & $\begin{array}{l}\text { Themes/patterns are built to describe } \\
\text { important main ideas }\end{array}$ & $\begin{array}{l}\text { What are stories of the disabled's sexual lives in common } \\
\text { and what are the differences? } \\
\text { What are the major themes that are dealt with? }\end{array}$ \\
\hline & Provides explanation and analysis, for & $\begin{array}{l}\text { What is disability? } \\
\text { Whex is it viewed in different contexts? }\end{array}$ \\
Structural analysis & ideas such as abstract concepts. & $\begin{array}{l}\text { Are there other factors to determine their understanding of } \\
\text { their sex lives and the self? }\end{array}$ \\
& & $\begin{array}{l}\text { Choice of words? } \\
\text { Which binary oppositions are represented in the story } \\
\text { (narratives)? }\end{array}$ \\
\hline $\begin{array}{l}\text { Dialogic/performance } \\
\text { analysis }\end{array}$ & Ideographs, metaphors & I do not have any visuals or pictures to analyze in this paper. \\
\hline Visual analysis & &
\end{tabular}

\section{Assessing the Autobiographical Narratives of Jhamak Ghimire and Parijaat}

Here, I have examined the autobiographical narratives of Jhamak Ghimire and Parijat respectively. I have analyzed what their narratives explore on their experiences and how they dispel the myth of disability as asexual, and how they explore their sexual identity on their journey to the quest for the self. In this section, I explored how and in what ways the works of physically challenged Nepali women express their subjective reality and lived experiences and personal identity. These writers, Parijat and Jhamak Ghimire, one suffering from paralysis and the other afflicted with cerebral palsy, overcame social prejudices and the limiting patriarchal definition of women's health, bodies, and sexuality through their writings. Their writings are a true reflection of their inner health and mindsets, and are also an example of their robust bodies despite the fact that they are not considered able-bodied and became objects of social abhorrence. They also express their love toward their own bodies, their lived experiences of their menstruation cycles, and other potentially limiting physical factors. Writing the disabled body in the hands of women with disabilities has become a powerful weapon to break free 
from the patriarchal definition of female's health and sexuality and move forward towards the quest for their self.

Parijat and Ghimire, were able to challenge social injustice and patriarchal control over their bodies, health, and sexuality. Both writers were physically incapacitated, but they did not hesitate to discuss their lives in terms of their hopes, dreams, and aspirations, including their sexuality, which is deemed a taboo subject in Nepalese society. This factor is a sign of women breaking into a stronghold of the world of men. Their ideas on sex are clearly revealed in their writings through poems and fiction. They give the reader a powerful evocation of their bodies and sexuality that helps to celebrate their own bodies as agencies that subvert the "ideology of ability" (Siebers, 2010, p. 10). The ideology of ability is woven with the capacity of one who can act like a "normate" human being (Siebers, 2010, p. 10). Being a "normal woman" encapsulates the ability of having traditionally accepted sexual intercourse and also having the capacity to bear children and maintain motherhood. The ideology of ability negates the ability of the disabled. In the context of south Asian countries like Nepal, the ideology of ability is formed through the lens of certain religious, social, and cultural practices in a particular space and time. Ghimire and Parijat have broken the chains of social stigma and established themselves as powerful women, and as real people writing about real, not imaginary, life experiences and showing their ability, creativity, and self-identity as sexual beings.

\section{Jhamak Ghimire: Dispelling the Myth of Disability as Asexual and Searching for the Self}

Jhamak Kumari Ghimire was born in Dhankuta, Nepal. She suffered from cerebral palsy which caused severe challenges to her. She did not have control of her arms, her speech, or have free bodily movement.

Ghimire identifies herself with the significance of sexual feelings. Ghimire (2014) wrote, "To be without sexual feelings is to be a person without emotion" (p. 36). The statement deconstructs the logic that disabled people do not have sexual feelings. Sexual feelings are related to human emotions, and not to have emotions is not to be a human being. This idea explicitly underscores the significance of sexual life which is hardly discussed in the lives of disabled women. Ghimire (2014) further writes, "Even if I cannot have a baby from my physical womb, I have given birth to many babies, and they all are from my brain" (p. 88). In a patriarchal society, if a woman cannot bear a child, she is deemed infertile and barren and is looked down upon. Even after babies are born, they are mostly recognized as born by their fathers, even in name. However, the phrase "they are all from my brain" signifies the narrator's creative works and that they all are recognized by her own name. Even if she is unable to give a physical birth to a baby, she has given birth to many poetic babies. Not only this, Ghimire (2010) explores her sexual freedom and ability and sexual identity indirectly in the poetic lines below:

Even the termites When their wings grow Enjoy freedom of flying in the sky By forgetting the dread of death How could the meaning of Being a human be Compared with a situation of Living a life of horrible fear In a cage. (Ghimire, 2010, p. 244)

The text questions that even if the insects enjoy the freedom of life, why not humans? The freedom might implicitly refer to the speaker's personal freedom in terms of identifying who she is, what she wants, and how she wants to define herself. Perhaps the narrator is indicating the conditions of a disabled life that has to live in a society that does not even have the value of an insect. However, the phrase "sprouting wings" signifies youth in the body and other desires and wants that need to be fulfilled as a sexual being. 
Ghimire underscores the significance and the role of menstruation as sexual being. She writes, "Menstruation also meant the flowering of youth..." (Ghimire, 2010, p. 115). Menstruation has a lot of significance as it signifies the adolescent stage a female enters, carrying meaning for her youth, beauty, readiness for marriage and motherhood, and so on. However, it is called impure and women are not allowed to touch during the menstruation cycle. In some societies, when a woman experiences their first period, she has to live far away from the house for 10 days without looking at the sunshine. There have been occasions when such separation causes death through snake bites and hyperthermia in a seclusion hut (Bhandari \& Najar, 2017).

Ghimire (2010) underscored the necessity of sex, physical desire, and love, which are considered irrelevant to the lives of women with disabilities. She felt her body, her growth, and her sexuality when she looked at herself in the mirror. She enjoyed the erotic feelings within her, the feelings that society thinks are either absent in the body of disabled women, a sign of moral decay, or a matter of taboo. Looking at the mirror, she wrote that when she looked at her vagina, she became amazed and overjoyed. Her vagina became a powerful metaphor and topic of discourse, referring to The Vagina Monologues (Ensler, 2001). She saw her vagina as a source of inspiration and joy, her beauty, and her life. She experienced her menstruation as a normal cycle of life in her body, but society put her away, saying that she was impure. She valued the significance of sex and asked people to respect it and recognize the sexual identity of women with disabilities.

The "ideology of ability" that "determines the value of some sexual practices and ideas" over disabled people (Siebers 2010, p. 136) does not allow one to think beyond the ideology box, but Ghimire (2010) brought to light what so-called able-bodied people tend to ignore in disabled bodies. Ghimire (2010) deconstructed the able-bodied idea of sex. Siebers (2010) observed that:

The idea of sex life is ablest, containing a discriminatory preference for ability over disability... One of the chief stereotypes oppressing disabled people is the myth that they do not experience sexual feelings or they do not have or want to have sex-in short, that they do not have a sexual culture. (p. 138)

Ghimire (2010) discussed her sex life, growth, and beauty by dismantling sex culture in the ablest society that determines how sex is viewed in the lives of women with disabilities, other than how disabled women themselves view sex and marriage. Ghimire (2010) realized what Siebers (2010) proposed about sexuality as a major part of a person's identity, that sexual liberation is good in itself, and that sexual expression is a civil right crucial to human happiness. This realization is evident when she described herself, her beauty, and the growth of her breasts in her autobiography. Siebers (2010) observed:

First, thinking about disabled sexuality broadens the definition of sexual behavior. Second, the sexual experiences of disabled people expose with great clarity both the fragile separation between the private and public spheres as well as the role played by this separation in the history of regulating sex. Third, co-thinking sex and disability reveals unacknowledged assumptions about the ability to have sex and how the ideology of ability determines the value of some sexual practices and ideas over others. Finally, the sexual history of disabled people makes it possible to theorize patterns of sexual abuse and victimization faced by other sexual minorities. (pp. 136-137)

Ghimire (2010) underscored a dilemma regarding the private and public life of a disabled woman. She was not afraid to discuss sex and genitalia that the able-bodied devalue as abnormal and asexual. The narratives bring her most private into public. She wrote that she had lost her shame because she could not cover her shame by herself. She needed someone to fix everything for her. As she grew, she became aware of it. She didn't let others get any enjoyment as they hurled pebbles attacking her private parts. Defining her beauty and sexuality, 
she narrated that when society does not credit one with the value of a potential human being, shame emerges, and sexuality remains distant. Thus, she addressed privacy by her narrative that reflects how people considered her asexual and abnormal.

Ghimire's (2010) narrative challenged the stereotypes that disabled people do not have or want to have sex and do not have a sexual culture. She broke the normative assumption about a sex life, love, and emotions and explored what it meant to have sexual identity. She explored her body and its growth, and her sexual life. Her narratives about her own body and sexuality help one explore disabled women's sexual identity and their quest for the self.

\section{Parijat: Dispelling the Myth of Disability as Asexual and Searching for the Self/Sexual Identity}

Bishnu Kumari Waiwa, also known as Parijat, was born in April 1937 in Darjeeling, India into a Lama family. She was given the name Chheku Dolma, which would immediately be recognized by Nepali Brahmins as Lama, an extremely low caste bordering on being an untouchable. Later, she changed it to Parijat, meaning night-flowering fragrant jasmine flower, the flower everyone would like to touch. From birth, Parijat was physically incapacitated and became sick very easily. When she turned thirteen, she suffered paralysis that left her with a lifelong weakness. Parijat could not move around easily due to her physical disability and family restrictions (Prasai, 2010). Parijat felt her home was like a prison. Thus, she was held captive by her own body (Prasai, 2010). Parijat was thus introspective from her early childhood.

Parijat's mother died when she was young, denying her a mother's love and care. Her father was authoritative and restricted her from various ordinary activities, including leaving the house on her own (Prasai 2010). Parijat's father, a homeopathic doctor, treated her unsympathetically, refusing to grant her the freedom to live as she liked. Parijat, at times, left home without getting her father's permission, which was against the traditional duty of a daughter. Prasai (2010) wrote that Parijat's father's authoritative and restrictive actions helped her fuel a revolutionary spirit against patriarchy which manifested itself in behaviors such as smoking marijuana, which was deemed to be consumed only by men. Smoking marijuana by a woman was and is still considered highly deviant, immoral, and against social norms and values. This suggests Parijat's defiance of her father's restrictions in patriarchal society. Despite the obstacles that her father, her society, and life put in her way, Parijat was able to overcome them and live as she chose, not how society anticipated her to live (Prasai, 2010).

As she got older, her health deteriorated, and she found herself suffering from a variety of illnesses. Later, she suffered from ulcers compounded by heavy drinking. Finally, she died on the 16th of April, 1992. She smoked, she drank, and she never got married. Smoking, drinking, and remaining unmarried were considered unusual in the life of a woman in Nepalese Society. Hutt (2008) wrote, "She is unmarried and childless, a status that is not usual for a woman in Nepalese society" (p. 111).

Most of Parijat's narratives "spring from her physical condition and from a profound atheism and moral despair" (Hutt, 2008, p. 113). Hutt (2008) proposed, "The themes and philosophical outlook of her poems, novels, and stories are influenced by her Marxist and feminist views and her own personal circumstances" (p. 111). This helps the reader to analyze her writing narratives critically.In her poem entitled "In the Arms of Death", Parijat expresses the outward appearance of an immobile body. The poem implicitly explains how her disabled body could be a barrier between her and other people because people ignored her as a person and 
focused on her disability. She emphasizes that she is more than just what people see with the naked eye. The death imagery she uses in her poetic narrative underscores her disability; her body which cannot move as freely as a normal body does. She compares the bed to the tomb, and she calls herself an "undying ghost". The knowledge of her embodiment and her writing narratives share helps one understand the disabled body from the disabled's perspective. However, Parijat displays her willingness to welcome death and celebrate her disabled body which does not hope for or invite any sympathies from others.

Parijat deconstructs the notion of disabled people as being asexual. She expresses her love for life, unrequited emotions, and lack of motherhood which are explored in the poem titled "To Gopal Prasad Rimal". Parijat points out that she cannot give the "ideals of motherhood", which is an element that authenticates women's gender and sexual identity in the Nepali society. However, she becomes critical of this notion motherhood. The way motherhood is defined or studied in the body of the disabled does not reflect the reality of how motherhood is defined by the disabled body. It is not only linked to the idea of marriage and child bearing, but also is connected to ideas beyond the confinement of marriage. Parijat expresses her love, freedom, a desire, and the beauty of body although her own physical body is incapable of moving freely:

Life companion, much, much love; I feel I might send you a heart I feel I might send you a love letter, Tied round the necks of these free-flying pigeons, Repeating the sentiments of last century's love, But what free bird could fly Across today's lines and borders, With what sighs could this withered existence Lay down to rest in the winds of this world?

(A sick lover's letter to her soldier translated and edited by Michael Hutt, 115).

Even if Parijat does not describe explicit experiences as Ghimire does, she has represented herself in most of her fictional works, such as a novel and poems where her main characters are disabled. And most of the characters deal with beauty, sex, femininity, love, sexuality, and growth that are seldom considered in the life of one with disabilities, by transgressing the taboos. Regarding sex, Parijat (2010) writes, "Theoretically, I agree that sexual intercourse is a natural and desirable process of creation. It maybe that this process is beautiful in itself or it may be that this process may not have any relation with beauty and limited only to physical happiness and satisfaction— but I searched for the beauty in it and I proceeded forward into the sex world” (p. 79).

In one of her most powerful novels, Shirish Ko Ful (also translated into English as Blue Mimosa), Parijat elevates the position of the female with disability higher than the able-bodied man. For example, Suyog, a male character in the novel, fails to meet, converse, and argue with the female character named Bari, but Bari, who is physically handicapped, teases him to get married. In her another Nepali novel, Mahatahin, meaning absurdity, Parijat's narratives make the reader wonder about the narrator's sexuality, unfulfilled desires, and dreams. Parijat (2013) writes, "His naked arms' chilliness was circulating through my body like an electric current" (p. 5 , translated mine). The first person narrator of the novel wonders about marriage, and the description is filled with sexual overtones and desires. At times, the narrator says, "The purpose of marriage was just to find a wife for me. Besides that, I had no other ambitions at all" (Parijat, 2013, p. 10, translation mine). This shows the narrator's desire for sex along with marriage, which deconstructs the concept of how the disabled body is viewed as asexual. At times, the narrator imagines jealousy and sexual gratifications with another character named Shiya and that explodes in his imagination this way: "Perhaps Shiya must have been sleeping with her pillar like thighs unzipped and I am not sure if there must be someone consuming her" (Parijat, 2013, p. 30). The narrator seems to be imagining the absurdity of life without sex as the narrator says this at one point: "As I am going to misbehave with my own existence, or say, as I am going to kill myself, why should I not misbehave with the balloon I have? 
Why should I not hug it tightly? Why should I not rape it?" (Parijat, 2013, p. 32). These narratives from Parijat show sexual prowess in a context in which disabled people are deemed to be asexual, and therefore, unfit for marriage.

In "A Sick Lover's Letter to Her Soldier", Parijat's body becomes a metaphor for the flower, a nature that passes through many seasons and obstacles. Regarding sex and love, Parijat thinks of them as a necessity and a natural process. According to Parijat, to have sex is easier than to love someone, and she expresses her unfulfilled physical desire for her first love because of her lower social status (Prasai, 2010). It was very hard for her to express her sexual or marital desire explicitly in the context in which she was a female on the one hand and had come from Dalit family on the other, plus she was disabled.

Parijat's poetic narratives explore her own disabled body, which is unlike how Nepali society views it, and unlike what male bodies or non-disabled bodies have set as norms. For example, in her poetic narratives, Parijat expresses her love, freedom, desire, and the beauty of body, although her own physical body is incapable of moving freely. Parijat's narratives deal with beauty, sex, love, sexuality, and growth, which are rarely considered in the lives of disabled women. Parijat (1980) writes, "My yearning for him increased, I told him without looking at him" (p. 99). The statement reflects on Nepali society which is closed. Even if one has desires and feelings toward someone, she keeps it inside herself. She cannot look at a man straight in his face. The society is slightly changed now, however, it reflects on the narrator's time. The narrator expressed her desire challenging the closed society. She further writes through one of the characters in her novel, "I wanted to scream like a hysterical person across the night time, 'Bari, I thought I fell in love with you' but I started panicking not being able to bear the load of this mockery" (Parijat, 1980, p. 25). Women are deemed to be prone to hysterics and the narrator without any hesitation wants to shout like a hysterical person.

In her narratives, Parijat implicitly asks who can say the disabled body does not have feelings, emotions, and the desire to love and be loved. The narratives echo desires and emotions of disabled women that people in general fail to see. People look upon the disabled body as crippled without desire for love and sex. Parijat's narratives define her disabled body not merely a flesh, but locating love, emotions, and other desires in the flesh. Parijat defines love as "union of bodies" that rises like a phoenix. Using an allusion to the mythological bird phoenix that is forever reborn from ashes, Parijat shows the stamina of disabled women who otherwise are deemed to be languishing in the ashes of their lives. Parijat raises disabled women's voices, the voices of love, sex, and marriage of disabled that are hardly discussed as key psychological and emotional aspects of disabled lives.

\section{Conclusion: Quest for the Self and Sexual Identity}

Based on the personal narratives of the disabled women, it shows who disabled people are and what they can do. Disabled women are:

- People with love, emotion, and humanity,

- Persons with sexual feelings and desire of motherhood,

- Creative,

- Pious and free,

- Full of the color of youth,

- Creative and can have mental wombs,

- Fertile and can marry, have children, and motherhood, 
- Loving and can "unbutton the blouse of love".

The autobiographical narratives of Parijat and Jhamak Ghimire prove the way disability is deemed at times, such as "mentally impaired" is replaced, based on the disabled women's narrative, with "creative", "lack of motherhood" with "can create mental womb", "untouchable" with "pious and free", "cannot marry" with "can marry", "do not have feelings" with "can unbutton the blouse of love", "damaged health" with "robust mind", and with "love, emotion, and humanity", and "life in death" with "freedom within". The disabled women's narratives, most of imageries/ideographs disabled women come up with, have the overtones of desires for love, relationship, marriage, and sex. This touches on sex and marriage. This theme focuses on the narratives of disabled women that touched on different aspects of disabled women's desires, such as husband, being a wife or mother, getting married, sexuality, youth, and other discussions related to love and affection, erotic desires, and wishes. Some of the symbols used in the narratives include: "glimpses of youth and sexuality", "bloom and flower", "color of youth", "deck my forehead", and "sexual feelings".

Sexuality, marriage, beauty, and love are very dominant themes in most of the narratives of the disabled women. Their narratives emphasize these themes as tools to liberate, emancipate, and unfetter themselves from the bondage of the society. It shows how the disabled women are aware of their bodies and sexuality while the society ignores and considers disabled beings as asexual.

It is clear that the society makes fun of the disabled women's sexuality and doubts their desire to be a mother. Some of the questions the poetic narratives bring in are: Don't the disabled have feelings? Don't they have desires for love? Love, yearning, and desire are recurring themes in most of the narratives of the disabled women to underscore their self and sexual identity.

Their autobiographical narratives explore how happy the women become when they look at themselves in the mirror and find themselves sexy and beautiful, when they find the adolescence in themselves and their well-developed bodily organs.

Their narratives invited us to understand motherhood, love, and sex in the life of women with disabilities and also to explore the significance of sex and gender identity and the recognition of the self in the context of Nepal that shaped people's understanding of ability. The narratives of women with disabilities in Nepal showed how they experienced a double and sometimes a triple disadvantage because they were viewed as being part of the inferior sex, along with other biased cultural beliefs that prevented them from exploring their desires for love and marriage and their self and sexual identity. It is clear that there was the absence of attention to sexual and emotional aspects of the disabled women.

Stigmatization excludes people who do not fit the category of normal. The narratives have problematized these categories for the disabled and advocate for the ability of the disabled saying disabled are sexual, ready for marriage, and capable for doing anything that an able-bodied person can do.

The symbols extracted from disabled women writers' non-fictional narratives not only reflect the conditions of the disabled women but also explore their emotional and psychological dimensions, such as desire for love and sex and marriage and how sex and gender play a crucial role in defining the nature of a disability. The narratives of the disabled writers have deconstructed the social perceptions of disabled women as asexual.

Traditional aspects of femininity and sexuality need to be recognized. Women with disabilities have fear, shame, and insecurities about their sexuality that may limit their sexuality (Bernert \& Ogletree, 2012; Bernert, 2011). The barrier lies not in the inability to develop responsible social and sexual behaviors, but in the 
misapprehensions and collective negative attitudes of some administrators, professionals, and family members, as well as the uninformed general public.

Finally, these disabled Nepali women writers are able to expose the gendered sex issues of disabled women and the issues of love, life, and liberty. They are able to subvert the negative images of disabilities and replace them with images that claim their beauty, difference, humanity, and sexuality in a way that is public.

Motherhood, beauty, and sexuality are viewed as central attributes for women in Nepali society where marriages are arranged, and where having a beautiful wife capable of bearing children is the goal of all men looking for a bride. However, most of their narratives explored how society denied these essential roles of being a female or expressing their true sexuality.

Understanding the disabled women expressed in the words that they have used to write their body, sexuality, and their lived experiences in general deconstruct the notion that disabled women are asexual and without feelings. The narratives of disabled women writers have explored their living experience that help one understand marriage and sexuality, illness, pain, and disability in the lives of the disabled women and can reshape views of the bodies of disabled women. The narratives of disabled women show how society, culture, and the body are linked in the disabled female person and how disabled women deconstruct the ideology of ability that stigmatizes disabled people.

\section{References}

Acharya, T. P. (2005). Gender discrimination and women empowerment. The Rising Nepal (daily). Kathamndu: Gorkha Publication.

Bamberg, M. (2003). Stories, tellings, and identities. In C. Daiute and C. Lightfoot (Eds.), Narrative analysis: Studying the development of individuals in society (pp. 135-157). London: Sage.

Bamberg, M. (2011). Who am I? Narration and its contribution for self and identity. Theory \& psychology. (in press)

Bamberg, M., \& Georgakopoulou, A. (2008). Small stories as a new perspective in narrative and identity analysis. Text \& Talk, 28(3), 377-396.

Bernert D. J., \& Ogletree, R. J. (2012). Women with intellectual disabilities talk about their perception of sex. Journal of Intellectual Disability Research, 57(3), 240-249.

Bernert, D. J. (2011). Sexuality and disability in the lives of women with intellectual disabilities. Sex Disability, 29, 129-141.

Bruner, J. (1991). The narrative construction of reality. Critical Inquiry, 18(1), 1-21.

Cameron, M. M. (1998). On the edge of the auspicious: Gender and castes in Nepal. New York, NY: Macmillan: University of Illinois Press.

Cuthbert, K. (2017). You have to be normal to be abnormal: An empirically grounded exploration of the intersection of asexuality and disability. Sociology, 51(2), 241-257. https://doi.org/10.1177/0038038515587639

Czarniawska, B. (2004). Narratives in social science research. London, UK: SAGE Publications.

Dhungana, B. M. (2006). The lives of disabled women in Nepal: Vulnerability without support. Disability \& Society, 21(2), $133-146$.

Ensler, E. (2001). The vagina monologues. Darmatist play service, Inc.

Feldman, M. S., Skoldberg, K., \& Brown, R. N. (2004). Making sense of stories: A rhetorical approach to narrative analysis. Journal of Public Administration Research and Theory, 14(2), 147-170.

Ghai, A. (2002). Disabled women: An excluded agenda of Indian feminism. Hypatia, 17, 49-66.

Ghai, A. (2003). (Dis)Embodied form: Issues of disabled women. New Delhi, India: Har-Anand Publications.

Ghimire, J. (2010/2012). In N. Sharma and S. Sharma (Trans.), Bhattarai, G. B. (Ed.), A flower in the midst of thorns. Kathmandu: Oriental Publication House.

Ghimire, J. (2014). Samaya-Bimba. Kathmandu, Nepal: Sabdahar Creations.

Giami, A. (1987). Coping with the sexuality of the disabled: A comparison of the physically disabled and mentally retarded. International Journal of Rehabilitation Research, 10(1), 41-48. http://dx.doi.org/10.1097/00004356-198703000-00004 
Greene, S. (2015). Gender and sexuality in Nepal: The experience of sexual and gender minorities in a rapidly changing social climate. Independent Study Project Collection (2093). Retrieved from $\mathrm{http} / / /$ digitalcollections.sit.edu/cgi/viewcontent.cgi?article=3115\&context=isp_collection

Griffiths, M., \& Macleod, G. (2008). Personal narratives and policy: Never the twain? Journal of Philosophy and Education, 42(1), 121-142.

Groce, N. E. (1997). Women with disabilities in the developing world: Arenas for policy revision and programmatic change. Journal of Disability Studies, 8(1/2), 177-193.

Hutt, M. (2008). Himalaya voices: An introduction to modern Nepali literature.Berkely: University of California Press.

Kim, E. (2011). Asexuality in disability narratives. Sexualities, 14(4), 479-493. https://doi.org/10.1177/1363460711406463

Lyotard, J. F. (1984). in G. Bennington and B. Massumi (Trans.), The postmodern condition: A report on knowledge. Minneapolis, MN: University of Minnesota Press.

Mahoney, M. R. (1991). Legal images of battered women: Redefining the issues of separation. Michigan Law Review, 90, 1-94.

Malhotra, R., \& Rowe, M. (2013). Exploring disability identity and disability rights through narratives: Finding a voice of their own. Taylor and Francis.

McCabe, M. P. (1999). Sexual knowledge, experience and feelings among people with disability. Sexuality and Disability, 17(2), 157-170. https://doi.org/10.1023/A:1021476418440

McRuer, R., \& Mollow, A. (2012). Sex and disability. New York, NY: Duke University Press.

Nosek, M. A., Howland, C. A., Young, M. E., Georgiou, D., Rintala, D. H., Foley, C. C., Bennett, L. L., \& Smith, Q. (1994). Wellness models and sexuality among women with physical disabilities. Journal of Applied Rehabilitation Counseling, 25(1), 50-58.

O’Toole, C. J., \& Bregante, J. L. (1992). Disabled women: The myth of asexual women. In S. S. Klein (Ed.), Sex, equity, and sexuality in education (pp. 273-304). Albany, NY: SUNY Press.

Parijat. (1980). Shirishkoful, blue mimosa. Sajha Prakashan. Kathmandu, Nepal.

Parijat. (2013). Mahatahin. Sajhaprakashan. Kathmandu, Nepal.

Prasai, N. R. (2010). The legend of literature: A biography of Parijat. Kathmandu: Ekta Publication.

Rahman, A. (1993). Women with disabilities in Bangladesh. A Journal of Canadian Women Studies, 13(4), 47.

Randall, W. L. (1995). The stories we are: An essay on self-creation. Toronto, Canada: University of Toronto Press.

Riessman, C. K. (2008). Narrative methods for the human sciences. London, UK: SAGE Publications.

Rogers, C. (2016). Intellectual disability and sexuality: On the agenda? Sexualities, 19(5-6), 617-622. https://doi.org/10.1177/1363460715620563

Sandowski, C. (1993). Responding to the sexual concerns of people with disabilities. Journal of Social Work and Human Sexuality, 8(2), 29-43. https://doi.org/10.1300/J291v08n02_02

Shakespeare, T. (2000). Help. London, UK: Venture Press.

Shuttleworth, R., Russel, C., \& Weerakoon, P. (2010). Sexuality in residential aged care: A survey of perceptions and policies in Australian nursing homes. Sex and Disability, 28(3), 187-194. https://doi.org/10.1007/s11195-010-9164-6

Stevens, B. (2008). Managing unruly bodies: Public policy and disability sexuality. Review of Disability Studies, 4(4), 15-22.

Wilkerson, A. (2002). Disability, sex radicalism, and political agency. NAWSA Journal, 14(3), 34-57. https://www.jstor.org/stable/4316923 